\title{
THE COMPLEMENT CONTENT OF HUMAN SERA WITH ESPECIAL REFERENCE TO MALARIA ${ }^{1}$
}

\author{
By ANNA DEAN DULANEY, with the technical assistance of JANE B. PRIEST, \\ MARY LOU ALMEDA, AND BII PARKER \\ (From the Division of Pathology and Bacteriology, University of Tennessee College \\ of Medicine, Memphis)
}

(Received for publication October 20, 1947)

Our interest in the complement content of sera from healthy and diseased individuals was initiated by chance observations on the cephalincholesterol flocculation test (1). In our first performance of the test we inadvertently included several sera which had been inactivated and stored in the refrigerator over-night. All of these gave positive readings at 24 hours. Repetition of these tests, using sera from the same individuals, but fresh samples which were less than four hours old, yielded some negative and some positive reactions.

It appeared that heating sera at $56^{\circ} \mathrm{C}$. for 30 minutes might have played a part in the nonspecific reactions with the cephalin-cholesterol antigen. Sera from 20 healthy individuals were therefore tested before and after inactivation. None of the 20 sera gave positive readings before inactivation, whereas five gave readings after heating which would be considered significant.

These results demonstrated that certain normal sera may be altered by inactivation to the extent that they give false positive cephalin-cholesterol reactions. The mechanism of inactivation is not altogether understood. One important result has to do with the destruction of the hemolytic property of the serum. Denaturation of proteins may occur and there may be loss of stabilizing property. However, determination of the complement content of these 20 sera, according to methods described later in this report, revealed no differences which could be related to the cephalin-cholesterol flocculation test. Later it was found that the addition of varying amounts of complement or albumin to positively reacting sera, or to normal sera which gave positive reactions after inactivation, did not inhibit the positive reaction.

\footnotetext{
1 These studies were supported in parts by grants-inaid from the Tennessee Valley Authority and from the United States Public Health Service.
}

In review of papers regarding the basic principle of the cephalin-cholesterol reaction, it was found that Kabat et al. (1943) (2) had observed the same non-specific reactions given by certain sera after inactivation and ice-box storage. They removed the complement from two normal sera by means of the precipitate formed by addition of purified rabbit Type III antipneumococcus nitrogen and Type III polysaccharide without development of a positive cephalin reaction.

These preliminary observations led us to study the complement content of sera from normal and diseased individuals. The recent papers of Wassermann and Alberts (1940) (3), Rutstein and Walker (1942) (4), Traub (1943) (5), Pohl and Rutstein (1944) (6), and of Ecker et al. (1946) $(7,8)$ demonstrate the renewed interest in the subject of complement in various clinical states. Ecker and his group have reviewed the considerable series of papers which have to do with complement in infectious diseases of man. They suggest that the lack of uniform technic explains in part the marked "contraindications and inconsistencies" of data. In their study of complement in 278 cases of various infectious diseases they determined the titers of the individual complement components as well as the inclusive titers. All other reports, including this one, record the overall titers.

We were particularly interested in the complement content of malarious sera and in the possible correlation with parasite count and other laboratory and clinical data. No complete data on complement in human malaria are available, although the papers of Cathoire (1910) (9), Vincent (1910) (10), Radosavjevic (1923) (11), and Wendlberger and Volavsek (1934) (12) state that complement is reduced in malaria and that such a decrease is most marked after several paroxysms. Roy and Mukerjee (1942) (13) re- 
port that complement is diminished in monkey malaria of $P$. knowlesi origin.

In this laboratory the amount of complement in milliliters required for 50 per cent hemolysis was determined for the following groups: (1) 30 normal healthy individuals, (2) 25 patients with liver disease, (3) 32 persons with various types of non-infectious disease, and (4) 24 neurosyphilitics before and after induced malaria. Single samples of sera were in most instances tested for the first three groups while multiple determinations were made on all but three of the patients inoculated with malaria. In all, a total of 264 determinations of complement titer were performed on 111 individuals.

\section{METHODS}

For the determination of the 50 per cent unit of complement the method of Kent, Bukantz and Rein (14) was followed with slight modifications.

Collection of sera: With the exception of a small number of malarious sera, collected at different times during the paroxysms, all of the bloods represented early morning samples $(8$ a.m.) from fasting individuals. The sera were stored at $4^{\circ} \mathrm{C}$. until the titrations were carried out. All titrations were performed within a period of four to five hours after collection of the blood samples.

Complement titration: Sera were routinely titrated in two dilutions. In most instances dilutions of $1: 30$ and 1:40 yielded satisfactory results. With sera showing diminished complement it was necessary to employ dilutions of $1: 20$ and $1: 10$, or even zero.

A 2 per cent suspension of sheep red cells was used. The blood was obtained from the same group of sheep, each of which had been tested as to red blood cell count and suitability for use in hemolytic systems. The blood was collected each week in Alsever's solution.2 On the day of use the citrated blood was filtered through gauze into a $15-\mathrm{ml}$. centrifuge tube and centrifuged. The packed cells were washed three times with physiological saline, all centrifugations being carried out at 2000 r.p.m. for ten minutes. A 2 per cent cell suspension was prepared, and after thorough mixing $1.2 \mathrm{ml}$. were pipetted to each of two Klett tubes and $4.8 \mathrm{ml}$. of cold distilled water added. After centrifugation at 2000 r.p.m. for five minutes readings were made in the Klett-Summerson colorimeter, using a green filter. The red cell suspension usually read at, or close to, $350 .{ }^{3}$ Adjustments to this figure were made by removal or addition of saline to the stock suspension, according to the formula

$$
\mathrm{Vol}_{2}=\frac{\text { Vol }_{2} \times \text { Klett reading }}{350} \text {. }
$$

\footnotetext{
2 As described (14).

3 This reading has been found to correspond with a cell concentration of 500,000 per cu. mm.
}

The adjusted suspension was checked in the manner described above.

The same lot of stock hemolysin was used throughout these studies. Titrations of diluted hemolysin were made at intervals to insure use of the optimal unit (15). One such unit of hemolysin in an equal volume of physiological saline was used for sensitization of the sheep red cell suspension.

Klett tubes were used for the complement titrations and Table $I$ indicates the amounts of the reagents employed.

TABLE I

Amounts of reagents (in ml.) employed in titration of complement

\begin{tabular}{|c|c|c|c|c|c|c|c|c|c|}
\hline Tubes & 1 & 2 & 3 & 4 & 5 & 6 & \multicolumn{2}{|c|}{$\begin{array}{c}100 \% \\
\text { Con- } \\
\text { trol }\end{array}$} & $\mid \begin{array}{c}0 \\
\text { Con- } \\
\text { trol }\end{array}$ \\
\hline $\begin{array}{l}\text { Diluted serum } \\
\text { Saline } \\
\text { Sensitized cells } \\
\text { Cold distilled } \\
\text { water }\end{array}$ & $\begin{array}{c}0.6 \\
3.0 \\
2.4 \\
0\end{array}$ & $\begin{array}{c}0.75 \\
2.85 \\
2.4 \\
0\end{array}$ & $\begin{array}{c}0.9 \\
2.7 \\
2.4 \\
0\end{array}$ & $\begin{array}{c}1.05 \\
2.55 \\
2.4 \\
0\end{array}$ & $\begin{array}{c}1.2 \\
2.4 \\
2.4 \\
0\end{array}$ & $\begin{array}{c}1.35 \\
2.25 \\
2.4 \\
0\end{array}$ & $\begin{array}{l}0 \\
0 \\
2.4 \\
3.6\end{array}$ & $\begin{array}{l}0 \\
0 \\
2.4 \\
3.6\end{array}$ & $\begin{array}{l}0 \\
3.6 \\
2.4 \\
0\end{array}$ \\
\hline
\end{tabular}

After an incubation period of 30 minutes in a $37^{\circ} \mathrm{C}$. water bath the tubes were centrifuged at 2000 r.p.m. for 10 minutes and examined in the colorimeter. The percentage of hemolysis was determined for each tube by comparison with the 100 per cent hemolytic and negative controls. A conversion table (Kent) was employed for adjustment and the average of readings in the $20-80$ per cent hemolytic range recorded. This average reading divided by the figure representing the serum dilution gave the volume in milliliters of complement required for 50 per cent hemolysis.

\section{RESULTS}

Normal healthy individuals: The 50 per cent complement titer of this group of 30 ranged from $0.0032 \mathrm{ml}$. to $0.006 \mathrm{ml}$. Six individuals yielded titers of $0.003-0.0039 \mathrm{ml}$; $15,0.004-0.0049 \mathrm{ml}$; eight, $0.005-0.0059 \mathrm{ml}$. while one titer exceeded $0.006 \mathrm{ml}$. The average titer was $0.0045 \mathrm{ml}$.

These data correspond very closely to those of Rutstein and Walker (4) for 54 healthy individuals. They followed the technic of Wadsworth, Maltaner and Maltaner (16) for the determination of the volume of blood serum in milliliters required to produce 50 per cent hemolysis and report a range of $0.0029-0.006 \mathrm{ml}$. Forty-two (80 per cent) of their group gave values of 0.004 $0.0059 \mathrm{mi}$. In our series, 23 (77 per cent) of the 30 patients showed values of $0.004-0.0059 \mathrm{ml}$. In a subsequent paper Pohl and Rutstein (6) report observations on 71 normal individuals and state 
that the median amount of blood serum required for 50 per cent hemolysis was $0.0049 \mathrm{ml}$. This median was not related to age or sex. As stated above our median was $0.0045 \mathrm{ml}$. and this was not related to sex. There were no significant age differences.

Day-to-day variation in the complement content of healthy normal individuals appears to be slight. For example, we drew blood from B. E. for eight successive days. All samples were collected at approximately 8 a.m., prior to breakfast. The 50 per cent hemolytic units in milliliters were consecutively: $0.0042,0.0041,0.0038,0.0043$, $0.0041,0.0046,0.0039$, and 0.0041 . The slight differences in these values are regarded as insignificant.

Patients with liver disease: The 25 patients in this group included five with a diagnosis of acute infectious hepatitis; seven, portal cirrhosis; five, Laennec's cirrhosis; two, carcinoma of the liver; two, chronic alcoholism and four, miscellaneous classifications. Only one sample of serum was examined for 21 patients while four patients had two examinations each. The 50 per cent unit for one of these individuals read below $0.002 \mathrm{ml}$. while six read $0.002-0.0029 ; 12,0.003-0.0039$; four, 0.004-0.0049; two, 0.005-0.0059; and four over $0.006 \mathrm{ml}$.

These data suggest that even severe disease of the liver does not produce diminution of complement detectable by such random sampling. It is possible, of course, that had these patients been followed for a period of several weeks certain ones would have shown marked variation in their complement titers. It is our opinion that a diminution of complement is a part of the picture in all severe disease which threatens to overwhelm the host.

Patients with non-infectious diseases of various types: This group included 32 patients on whom 34 examinations were made. When these titers are compared with those of the normal group, or with those of patients with liver disease, it is apparent that there are no significant differences. Eight individuals gave titers of $0.002-0.0029 \mathrm{ml}$; $20,0.003-0.0039 \mathrm{ml}$., while there were two representatives in each of the groups, 0.004-0.0049, $0.005-0.0059$ and over $0.006 \mathrm{ml}$.

The average 50 per cent hemolytic titer for this group is $0.0036 \mathrm{ml}$., a figure which almost dupli- cates that of $0.0037 \mathrm{ml}$. for the patients with liver disease. Both of these medians are somewhat higher ${ }^{4}$ than that for the normal group $(0.0045$ ml.) but it is not believed that the difference, as based on one test, justifies the conclusion that complement is not decreased in the group of patients with non-infectious disease.

Patients with malaria: A total of 178 complement titrations were performed on 24 malarious patients. One observation was recorded for each of three patients and two to seven tests for each of 15 patients. A total of 112 titrations were carried out on six patients. One of these individuals had 11 tests; one, 12 tests; and one, 17 tests. Twenty-three successive titrations were conducted on each of two patients and 26 on another.

The distribution of complement titers in relation to the presence or absence of parasitemia in the individual samples of blood from the 24 malarious patients is presented in Table II.

TABLE II

The distribution of 178 complement titers for 24 malarious patients in relation to the presence or absence of demonstrable parasitemia

\begin{tabular}{l|c|c|c}
\hline \hline Ml. of serum & $\begin{array}{c}\text { No } \\
\text { parasitemia }\end{array}$ & $\begin{array}{c}\text { Parasitemia } \\
\text { present }\end{array}$ & Total \\
\cline { 2 - 4 } $0.002-0.0029$ & 1 & 4 & 5 \\
$0.003-0.0039$ & 19 & 20 & 39 \\
$0.004-0.0049$ & 24 & 20 & 44 \\
$0.005-0.0059$ & 8 & 23 & 31 \\
$0.006-0.0069$ & 1 & 9 & 10 \\
$0.007-0.0079$ & 1 & 5 & 6 \\
$0.008-0.0089$ & 1 & 3 & .4 \\
over 0.009* & 16 & 23 & 39 \\
\hline Total & 71 & 107 & 178 \\
\hline
\end{tabular}

* These titers were obtained with sera from patients P. W. and M. A. only.

Statistical analysis of these 178 titrations, considered as isolated observations, revealed no significant difference between the amount of complement required for 50 per cent hemolysis in bloods exhibiting parasitemia and in those free of parasites. There was likewise no correlation between the complement titer and the degree of parasitemia since high and low parasite counts are represented in all groups.

However, a study of the composite records of

4 The activity of complement is inversely related to volume. 
TABLE III

Pertinent clinical and laboratory findings for six patients with induced malaria

\begin{tabular}{|c|c|c|c|c|c|c|c|c|c|c|c|}
\hline Patient & $\begin{array}{c}\text { Type } \\
\text { of } \\
\text { malaria }\end{array}$ & $\begin{array}{c}\text { Period of } \\
\text { observa- } \\
\text { tion (days) }\end{array}$ & $\begin{array}{c}\text { Number } \\
\text { of } \\
\text { tests }\end{array}$ & $\begin{array}{c}\text { Days } \\
\text { between } \\
\text { tests }\end{array}$ & $\begin{array}{l}\text { Complement } \\
\text { titer before } \\
\text { inoculation }\end{array}$ & $\begin{array}{l}\text { Lowest } \\
\text { titer during } \\
\text { malaria }\end{array}$ & $\begin{array}{l}\text { Days } \\
\text { after } \\
\text { onset of } \\
\text { para- } \\
\text { sitemia }\end{array}$ & $\begin{array}{l}\text { Number } \\
\text { of par- } \\
\text { oxysms }\end{array}$ & $\begin{array}{l}\text { Hours } \\
\text { of } \\
\text { fever* }\end{array}$ & $\begin{array}{l}\text { Ceph- } \\
\text { chol- } \\
\text { floccula- } \\
\text { tion }\end{array}$ & $\begin{array}{l}\text { Clinical } \\
\text { course }\end{array}$ \\
\hline 1 & $\underset{\text { falciparum }}{P .}$ & 31 & 23 & $1-2$ & $0.0045 \mathrm{ml}$. & $0.01 \mathrm{ml}$. & 8 & 5 & 34 & 0 & $\begin{array}{l}\text { unevent- } \\
\text { ful }\end{array}$ \\
\hline $\begin{array}{l}2 \\
3 \\
4 \\
5\end{array}$ & $\begin{array}{c}P . \text { vivax } \\
P . \text { vivax } \\
P . \text { vivax } \\
P . \\
\text { falciparum }\end{array}$ & $\begin{array}{l}18 \\
33 \\
40 \\
25\end{array}$ & $\begin{array}{l}11 \\
23 \\
26 \\
17\end{array}$ & $\begin{array}{l}1-2 \\
1-2 \\
1-2 \\
1-2\end{array}$ & $\begin{array}{l}0.0056 \mathrm{ml} \text {. } \\
0.0048 \mathrm{ml} \text {. } \\
0.0039 \mathrm{ml} \text {. } \\
0.0046 \mathrm{ml} \text {. }\end{array}$ & $\begin{array}{l}0.043 \mathrm{ml} . \\
0.28 \mathrm{ml} . \\
0.25 \mathrm{ml} . \\
0.004 \mathrm{ml} .\end{array}$ & $\begin{array}{r}3 \\
15 \\
15 \\
11\end{array}$ & $\begin{array}{r}1 \\
11 \\
4 \\
5\end{array}$ & $\begin{array}{r}8 \\
51 \\
13 \\
23\end{array}$ & $\begin{array}{l}+ \\
+ \\
+ \\
0\end{array}$ & $\begin{array}{l}\text { severe } \\
\text { severe } \\
\text { severe } \\
\text { unevent- } \\
\text { ful }\end{array}$ \\
\hline 6 & $P$. vivax & 67 & 12 & $3-7$ & $0.0034 \mathrm{ml}$. & $0.005 \mathrm{ml}$. & 16 & 6 & 54 & + & $\begin{array}{l}\text { unevent- } \\
\text { ful }\end{array}$ \\
\hline
\end{tabular}

$* 103^{\circ} \mathrm{F}$. by rectum.

patients proves that complement is usually depressed during induced malaria. This diminution may be so slight that the lowest titer of some patients is still within the range exhibited by certain normal individuals and in such cases it may be demonstrated only by a series of examinations made at short intervals. Other patients may show marked decrease of complement. In general, complement decrease is a part of the picture of severe disease.

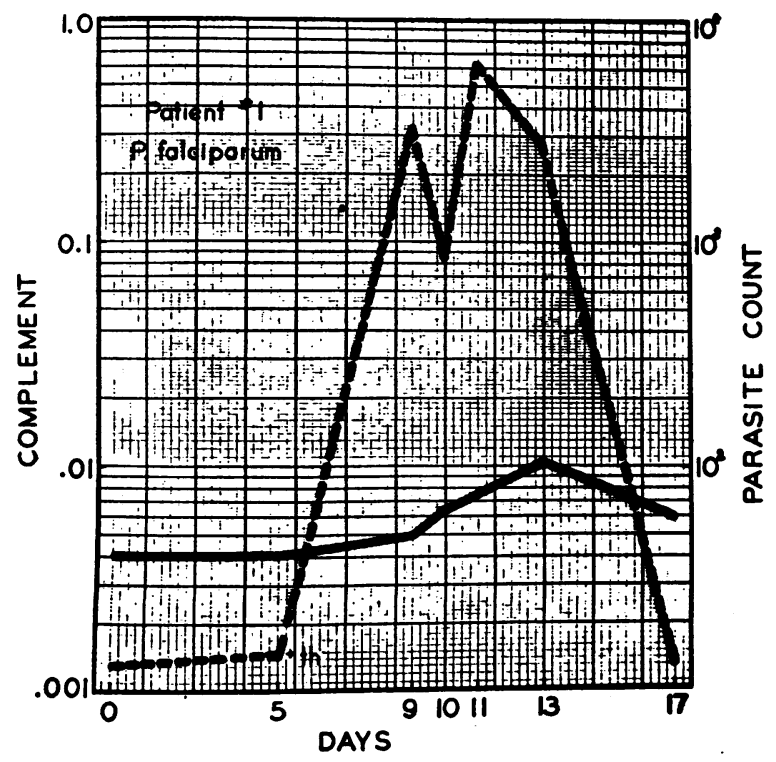

FIG. 1
Since it is believed that the data on the six patients followed over relatively long periods are most informative, these will be considered in detail. Table III gives the pertinent clinical and laboratory data, and Figures 1-6 show the trend of complement and parasitemia and indicate the significant changes which occurred after onset of parasitemia.

The individual records of eight patients on whom at least five titrations were performed are

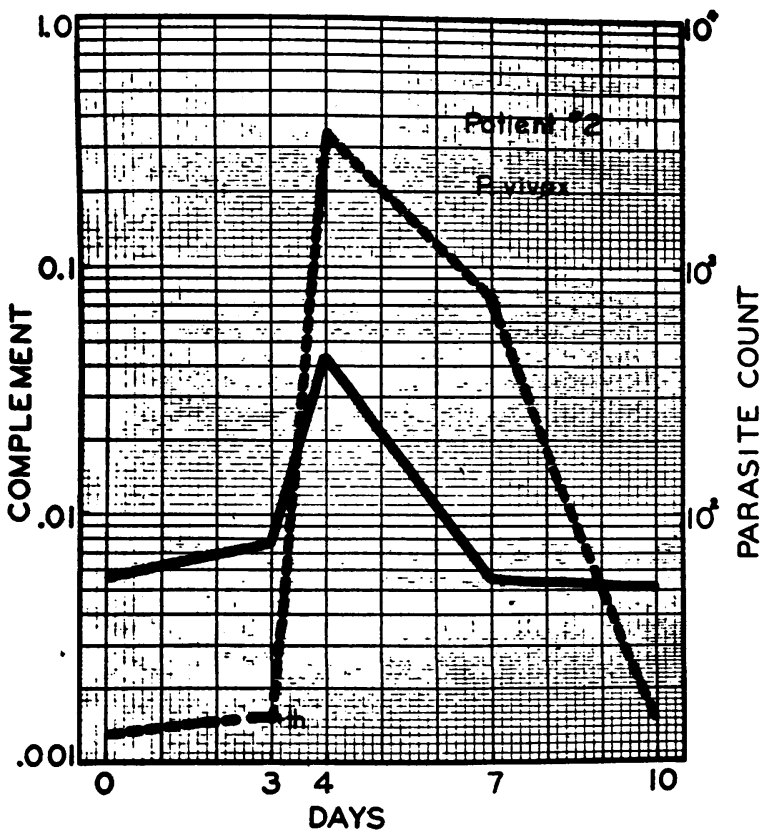

FIG. 2

Figs. 1-6. Showing Relationship of Parasite Count and Complement Content of Sera of Six Patients with Induced Malaria. The Amount of Complement Required for 50 Per Cent Hemolysis is Inversely Proportional to Titer 


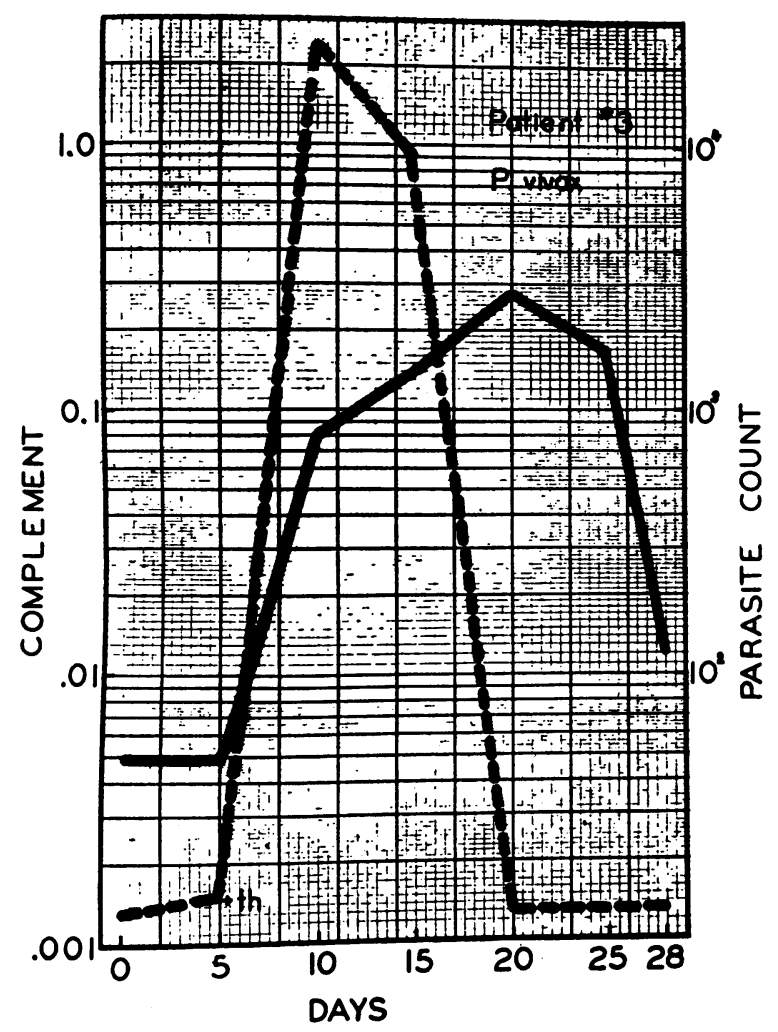

FIG. 3

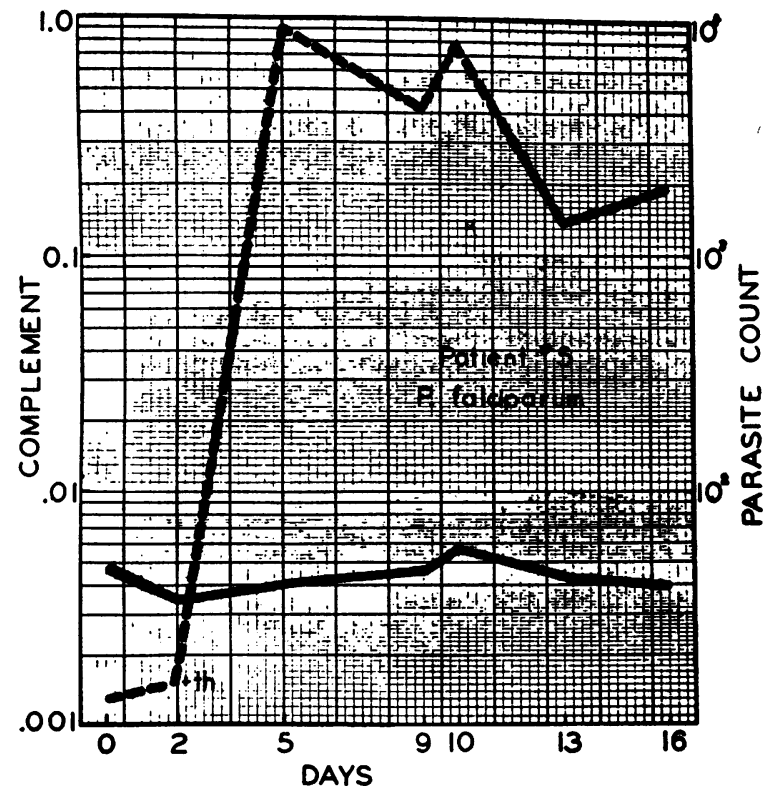

FIG. 5

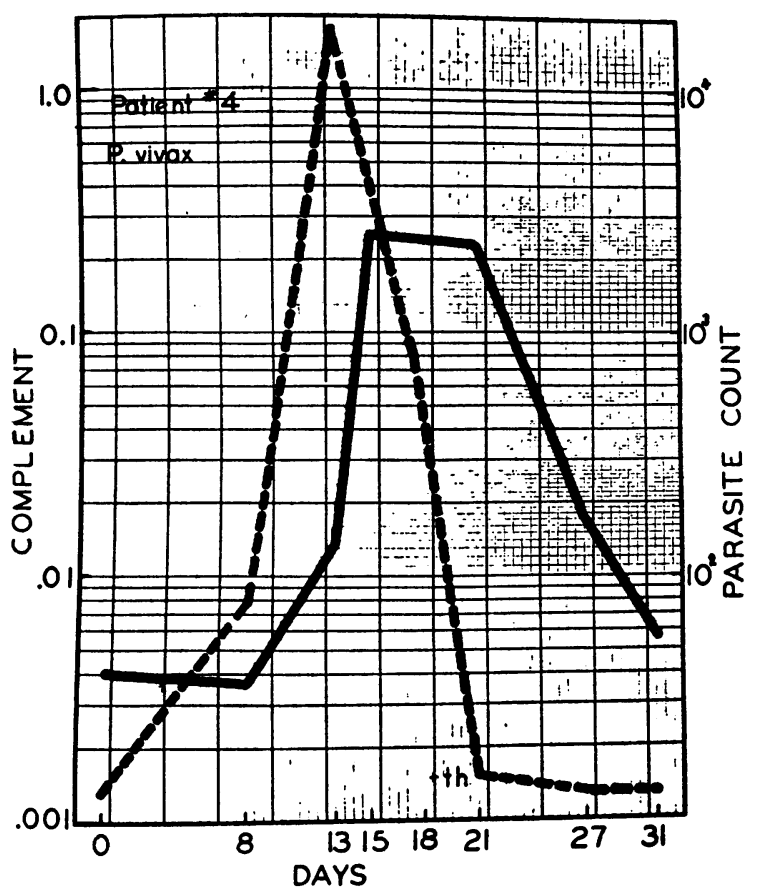

FIG. 4

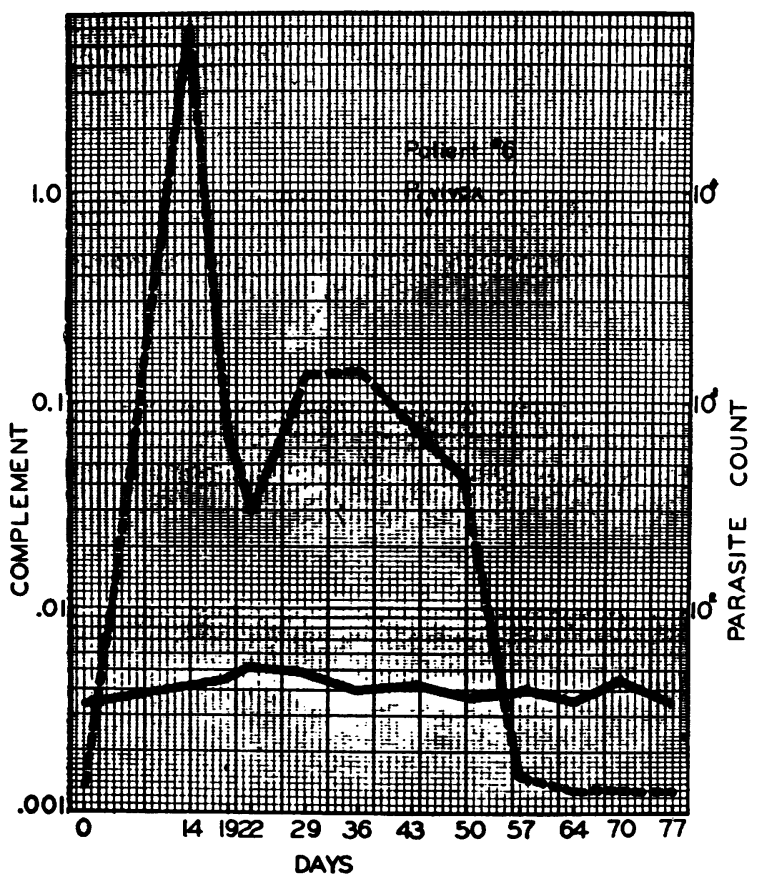

FIG. 6 
not included because of lack of space. It is emphasized that all eight followed the general pattern exhibited for malaria. There was a decrease in complement which coincided with, or followed, the peak of parasitemia. In none of these patients was the diminution of complement marked, or the duration of low level prolonged.

In none of the 24 patients was the titer before inoculation with malaria of a level significantly lower than that of the normal group. It is believed that the complement decreases were altogether due to malaria and that late syphilis could not be held responsible for the changes. It is recognized that similar studies in a non-syphilitic group are necessary for a dogmatic statement regarding this question.

\section{DISCUSSION}

We are not able to offer an explanation for the depression of complement which usually occurs in induced malaria. There is no doubt that the absolute decrease is correlated with parasitemia (Figures 1-6) since diminution of complement coincided with, or followed, the peak of parasite count. However, the relative decrease in complement cannot always be related to the height of the parasite count. For example, Patient VI exhibited the highest parasitemia of any patient with no marked changes in complement level. On the other hand the high parasite counts of $\mathrm{Pa}$ tients III and IV were accompanied by marked depression of complement. It is interesting that Rutstein and Walker could not relate pneumococcal bacteremia to low complement levels.

The lack of correlation between the numbers of parasites in the blood stream and complement titers would tend to refute any suggestion that complement was decreased as a part of the phagocytic process which is such an important mechanism in malaria.

It is well known that profound disturbances in serum proteins may occur during the course of malaria. There is a marked increase in gamma globulin with a relative decrease in albumin. Davis, Kabat, Harris, and Moore (17) have shown that the gamma globulin fraction of human serum separated by electrophoresis is often anticomplementary and they point out that sera from patients with certain infectious diseases characterized by marked increase in gamma globulin have been found anticomplementary. Parenthetically we may state that anticomplementary reactions were not infrequently encountered in sera from our group of malarious patients in complement fixation tests for malaria and syphilis. The possibility of in-vivo binding of complement by gamma globulins is interesting to consider. If this were the complete explanation, however, we would expect to demonstrate some correlation between depression of complement and a positive cephalin reaction. Our data do not point to this correlation. While it is true that the patients with severe malaria and coincident complement depression exhibited a positive cephalin test we may cite in contrast the patients with liver disease and a positive cephalin reaction whose blood serum showed high normal levels of complement.

Morrison, Block, and Jeskey (18) analyzed the plasma proteins of monkeys infected with $P$. knowlesi malaria. They found that the gamma globulins were increased at the expense of the albumins and that the $A / G$ ratio was correlated with duration of infection. In the malarious patients studied we could find no such relation between the low complement titer and duration of the disease. We were likewise unable to relate the complement titer to clinical or laboratory findings such as temperature, number of paroxysms, hours of fever, white blood cell count, cephalin flocculation test, or antibody titer.

At this time we can only emphasize that complement depression may be a part of the picture of malarial disease. It is our opinion that no simple explanation of this depression will suffice.

\section{CONCLUSIONS}

1. The over-all complement content of normal human sera (as based on the amount in milliliters required for 50 per cent hemolysis) is remarkably constant.

2. The 50 per cent hemolytic unit for normal individuals, as determined by the method employed by us, ranged from 0.0032 to $0.006 \mathrm{ml}$. with a median of $0.0045 \mathrm{ml}$.

3. Day-to-day variations in the complement content of normal individuals appear to be slight.

4. The complement level of sera (one sample) from patients with liver disease and from patients with non-infectious diseases of various types did 
not appear to be depressed. There was no correlation between complement titer and the results of the cephalin-cholesterol test.

5. Complement is usually diminished during the course of induced malaria. This decrease may be very slight or in severe disease it may be very marked. In general the complement titer reflects the severity of the disease, the balance between host and parasite. Complement titer cannot be correlated with parasite count, white blood cell count, temperature, number of paroxysms, hours of fever, cephalin flocculation test, or antibody titer.

6. In any study of complement as related to a particular disease, it is important that a series of determinations be carried out at short intervals during the course of the disease in order to detect changes which may occur.

\section{ACKNOWLEDGMENTS}

We express appreciation to: Dr. Y. T. Wong (Gailor Memorial Hospital) for collection of bloods from the malarious patients and for supplying clinical data; Dr. John Young (Dept. of Medicine) for collection of bloods from patients with liver disease and with non-infectious disease, and for classification of the patients; Dr. Frank L. Roberts (Dept. of Preventive Medicine) for statistical analysis of data; Capt. John F. Kent (Dept. of Serology, Army Medical Center) for the use of the conversion table and for valuable comments.

\section{BIBLIOGRAPHY}

1. Hanger, Franklin M., Serological differentiation of obstructive from hepatogenous jaundice by flocculation of cephalin-cholesterol emulsions. J. Clin. Invest., 1939, 18, 261.

2. Kabat, E. A., Hanger, F. M., Moore, D. H., and Landow, H., The relation of cephalin flocculation and colloidal gold reactions to the serum proteins. J. Clin. Invest., 1943, 22, 563.

3. Wassermann, P., and Alberts, E., Complement titer of blood of the newborn. Proc. Soc. Exper. Biol. \& Med., 1940, 45, 563.
4. Rutstein, D. D., and Walker, W. H., Complement activity in pneumonia. J. Clin. Invest., 1942, 21, 347.

5. Traub, B., The complement activity of the serum of healthy persons, mothers and new-born infants. J. Path. \& Bact., 1943, 55, 447.

6. Pohl, A. W., and Rutstein, D. D., The deterioration of complement activity in normal human serum. J. Clin. Invest., 1944, 23, 177.

7. Ecker, E. E., Seifter, S., Dozois, T. F., and Barr, L., Complement in infectious disease in man. J. Clin. Invest., 1946, 25, 800.

8. Seifter, S., and Ecker, E. E., Complement and isohemagglutinins in urinary proteins. J. Clin. Invest., 1946, 25, 809 .

9. Cathoire, E., Baisse du pouvoir alexique du sérum dans l'accès paludéen. Comptes Rend. Soc. de Biol., 1910, 69, 562.

10. Vincent, $H$., Note sur les variations du complément dans l'accès palustre. Ibid., 563.

11. Radosavjevíc, Alex., Ueber das Komplement bei Malaria. Ztschr. f. Immunitätsf. u. Exper. Therap. I. Teil Orig., 1923, 35, 429.

12. Wendlberger, J., and Volavsek, W., Uber Vergleichende Komplementuntersuchungen bei gonorrhoischen und rheumatischen Affektionen. Wien. klin. Wchnschr., 1934, 47, 967.

13. Roy, A. N., and Mukerjee, S., Some observations on complement in serum of monkeys during infection with plasmodium knowlesi. Ann. Biochem. \& Exper. Med., 1942, 2, 245.

14. Kent, J. F., Bukantz, S. C., and Rein, C. R., Studies in complement fixation. I. Spectrophotometric titration of complement; construction of graphs for direct determination of the 50 per cent hemolytic unit. J. Immunol., 1946, 53, 37.

15. Kent, John F., An abbreviated spectrophotometric technique for determining the optimal concentration of amboceptor. J. Lab. \& Clin. Med., 1946, 31, 1270.

16. Wadsworth, A., Maltaner, E., and Maltaner, F., Quantitative determination of fixation of complement by immune serum and antigen. J. Immunol., 1931, 21, 313.

17. Davis, B. D., Kabat, E. A., Harris, A., and Moore, D. H., The anticomplementary activity of serum gamma globulin. J. Immunol., 1944, 49, 223.

18. Morrison, D. B., Block, E. H., and Jeskey, H. A., Changes in the electrophoretic pattern of the plasma proteins of monkeys (Macaca mulatta) with infections. Federation Proc., Part II, 1947, 6, 279. 